\title{
Optimization of High Performance Liquid Chromatography Method for Simultaneous Determination of Some Purine and Pyrimidine Bases
}

\author{
Jernej Markelj, Tatjana Zupančič and Boris Pihlar* \\ Faculty of Chemistry and Chemical Technology, University of Ljubljana, Večna pot 113, 1000 Ljubljana, Slovenia \\ *Corresponding author: E-mail: boris.pihlar@fkkt.uni-lj.si \\ $+38614798552$
}

Received: 06-01-2015

\begin{abstract}
Nine purine and pyrimidine bases were separated and determined simultaneously using reversed phase (RP) high performance liquid chromatography (HPLC) in some food samples and biological fluids. Chromatographic behavior of these ionizable compounds highly depends on the interactions with the solvent as confirmed experimentally and by calculation of distribution of this species as a function of $\mathrm{pH}$. Chromatograms show the optimal separation of five purine (uric acid, hypoxanthine, xanthine, adenine, and guanosine), and four pyrimidine (cytosine, uracil, cytidine and tymine) bases at $\mathrm{pH}$ around four. Accordingly, acetate buffer was selected due to high buffer capacity in this region. By variation of $\mathrm{pH}$, concentration of buffer and volume ratio between buffer and methanol, we found that a mixture of $50 \mathrm{mM}$ acetate buffer of $\mathrm{pH} 4.0 \pm 0.1$ with $3 \%$ of methanol ensures reproducibility, complete separation in less than 15 minutes and compatibility with UV and MS detection. Developed screening method was validated and applied for the analysis of complex clinical and beverage samples.
\end{abstract}

Keywords: Reversed phase-HPLC, Purine and Pyrimidine Bases, Beer, Saliva, Urine

\section{Introduction}

Purine and pyrimidne bases and their nucleotides are involved in a numerous biochemical processes, and they play an important role in cell metabolism as monomeric precursors of RNA and DNA and as a secondary messenger. ${ }^{1}$ Their determination is very important in many areas of research, like clinical analysis,${ }^{2-7}$ or food and beverage analysis. In food analysis some of these compounds have been related to off-flavors in food, being a marker for its freshness, on the other hand the end product of purine catabolism in the human body is uric acid, which is known to be a major trigger for gout, a common disease in developed countries. Because of this, many analytical methods have been developed for determination of purine and pyrimidine bases. The most widely used technique for biological samples is reversed phase (RP) or RP ion-pairing ${ }^{15}$ high performance liquid chromatography (HPLC) because it gives reproducible results, and is sensitive, selective and easily automated. ${ }^{2-3,5-7,10,12-14}$ Capillary electrophoresis is also widely used for the separation of these analytes because of its minimal sample volume, short analysis time and high separation efficiency. ${ }^{16-18}$ For both techniques UV/VIS, ${ }^{5,18}$ electrochemical ${ }^{19}$ or MS detection is used. ${ }^{13-14,18,20-22}$ Since nucleobases are electroactive, in some papers voltammetric determination with static mercury drop electrode, by modified graphite/carbon electrodes, ${ }^{23-24}$ and on the boron-doped carbon nanotubes are also reported. ${ }^{27}$

In this study HPLC with isocratic elution with UV and MS detection was employed for the separation and determination of nine purine and pyrimidine bases. Since the majority of previous reports on HPLC separation of purine and pyrimidine bases were performed with phosphate buffers ${ }^{2,5-6,9-12,15}$ which according to our observation do not ensure satisfactory separation and reproducible retention in acidic region, the main aim of our research was to find better mobile phase and to optimize the conditions for their complete separation. Developed screening method was applied for the determination of free nucleobases in some beverage samples and biological fluids. 


\section{Experimental}

\section{1. Materials and Chemicals}

Purine (uric acid-UA, hypoxanthine-HY, xanthine$\mathrm{XA}$, adenine-AD, guanine-GUA, and guanosine-GU) and pyrimidine bases (cytosine-CS, uracil-UR, cytidine-CD, and tymine-TM) were all of $99 \%$ purity (except GU 98\%) and purchased from Sigma-Aldrich, Germany. For the preparation of buffers and mobile phases $99.5-100.5 \%$ $\mathrm{KH}_{2} \mathrm{PO}_{4}$ (Merck, Germany) and 98\% $\mathrm{K}_{2} \mathrm{HPO}_{4}$ (Kemika, Croatia), 99\% acetic acid and sodium acetate (Sigma-Aldrich, Germany), HPLC grade methanol (MeOH, J.T. Baker, Holland), 27\% $\mathrm{NH}_{3}$ (Sigma-Aldrich, Germany), 99\% $\mathrm{NaOH}$ (Merck, Germany), 37\% hydrochloric acid and $84 \%$ phosphoric acid (Riedel-De Häen, Germany) were used. Calibration of glass electrode (6.0234.100, pH 0-14, Metrohm, Switzerland) was performed with standard aqueous buffer solutions (Kemika, Croatia) and Milli-Q purified water (resistivity $>18 \mathrm{M} \Omega \mathrm{cm}$ ) was used for the preparation of working standards and solutions throughout the work.

\section{2. Apparatus and Chromatographic Conditions}

Liquid chromatographic system consisted of K-501 pump (Knauer, Germany), autosampler with injector (sample loop $20 \mu \mathrm{L}$ ) (Spark Basic Marathon, Holland), UV/VIS detector Smart Line UV 2500 (Knauer, Germany) and PC with software Basic Edition V3.05 (Knauer, Germany). An ultrasonicator Sonis 4 (Iskra, Slovenia) and a pH Meter 781 (Metrohm, Switzerland) were used.

Chromatographic separations were achieved on a RP column Kinetex ${ }^{\mathrm{TM}} \mathrm{C} 18(150 \mathrm{~mm} \times 4.6 \mathrm{~mm}$ i.d., $2.6 \mu \mathrm{m}$ particle size, pore size $100 \AA$ ) purchased by Phenomenex (Torrance, CA, USA). KrudKatcher ultra HPLC in-line filter $(0.5 \mu \mathrm{m}$, AFO-8497) (Phenomenex, USA) was used to protect the analytical column.

The following mobile phases were used: MP1 consisted of $50 \mathrm{mM}$ phosphate buffer prepared by mixing of $48 \mathrm{mM}$ of $\mathrm{KH}_{2} \mathrm{PO}_{4}$ and $2 \mathrm{mM} \mathrm{K} \mathrm{HPO}_{4}$ with methanol $(97: 3, \mathrm{v} / \mathrm{v})$. Final $\mathrm{pH}$ of buffer was adjusted to $\mathrm{pH} 4.0-6.5$ by dil. $\mathrm{H}_{3} \mathrm{PO}_{4}$ or $\mathrm{NaOH}$. MP2 contained $50 \mathrm{mM}$ (or 0.10 $\mathrm{M}$ and $0.20 \mathrm{M}$ ) acetate buffer of $\mathrm{pH} 4.0$ and methanol $(97: 3, v / v)$ if not stated otherwise. MP2 was prepared by mixing sodium acetate and acetic acid with the same concentration that was in final buffer, e.g. for preparation of $50 \mathrm{mM}$ acetate buffer $50 \mathrm{mM}$ sodium acetate and $50 \mathrm{mM}$ acetic acid was mixed. Since we wanted to prepare acetic buffer with $\mathrm{pH} 4.0$, we mixed sodium acetate and acetic acid in a volume ratio of 1.00 to 4.56 . $\mathrm{pH}$ of prepared buffers was always checked with calibrated $\mathrm{pH}$-meter and corrected if necessary by adding sodium acetate or acetic acid. The mobile phase was prepared daily and was filtered with $0.45 \mu \mathrm{m}$ membrane filter (Millipore, Germany) under vacuum. Flow-rate was $0.5 \mathrm{~mL} / \mathrm{min}$ and the detec- tor wavelength was set at $254 \mathrm{~nm}$. All assays were performed at ambient temperature.

For the confirmation of particular bases and by the analysis of real samples peak identity was determined by MDS SCIEX 3200Q LC/MS/MS spectrometer (Applied Biosystems, USA) with electrospray ionization (ESI) in multiple reaction monitoring (MRM) mode. The probe temperature was $250{ }^{\circ} \mathrm{C}$ and the capillary voltage was 4.5 $\mathrm{kV}$ in both positive and negative mode. Nitrogen gas (99.999\%) was used as desolvation gas, cone gas and also as collision gas. The curtain and nebulizer gas pressure were set at 10 and $20 \mathrm{psi}$, respectively, while the heater gas pressure was set at 40 psi. Optimal "transition pairs" (i.e. precursor/product ion) were found for each analyte and appropriate declustering potential (DP), entrance potential (EP), collision energy (CE) and collision exit potential (CXP) set: CS $m / z(+) 112 / 95$ (DP $40 \mathrm{~V}$, EP $10 \mathrm{~V}$, CE $25 \mathrm{~V}$, CXP 3 V); UR $\mathrm{m} / z$ (+) 113/96 (DP $23 \mathrm{~V}$, EP 10 $\mathrm{V}$, CE $25 \mathrm{~V}$, CXP $3 \mathrm{~V}$ ); CD m/z (+) 244/112 (DP $10 \mathrm{~V}$, EP $5 \mathrm{~V}$, CE $30 \mathrm{~V}$, CXP $4 \mathrm{~V}$ ); TM $\mathrm{m} / z$ (+) 127/110 (DP $30 \mathrm{~V}$, EP $5 \mathrm{~V}$, CE $20 \mathrm{~V}$, CXP $3 \mathrm{~V}$ ); AD $m / z$ (+) 136/119 (DP 35 $\mathrm{V}$, EP $5 \mathrm{~V}$, CE $25 \mathrm{~V}$, CXP $3 \mathrm{~V}$ ); UA $m / z$ (-) 167/124(DP $-30 \mathrm{~V}, \mathrm{EP}-5 \mathrm{~V}, \mathrm{CE}-24 \mathrm{~V}, \mathrm{CXP}-3 \mathrm{~V}$ ); HY m/z (-) 135/93 (DP $-40 \mathrm{~V}, \mathrm{EP}-5 \mathrm{~V}, \mathrm{CE}-15 \mathrm{~V}, \mathrm{CXP}-3 \mathrm{~V})$; XA $\mathrm{m} / z$ (-) 151/108 (DP -30 V, EP -5 V, CE -15 V, CXP -3 V); GU $m / z$ (-) 282/150 (DP -40 V, EP -5 V, CE -20 V, CXP -3 V); GUA $m / z$ (-) 150/133 (DP -25 V, EP -5 V, CE -14 V, CXP $-3 \mathrm{~V})$. Quadrupole mass analyzer was coupled to the chromatographic system and UV-VIS detector was connected between column and MS detector. For LC-MS analysis $50 \mathrm{mM}$ ammonium acetate buffer was prepared (MP3) by titration of $50 \mathrm{mM}$ acetic acid with $1 \mathrm{M}$ solution of $\mathrm{NH}_{3}$ to $\mathrm{pH} 4.0$, and mixed with methanol $(97: 3, \mathrm{v} / \mathrm{v})$.

\section{3. Preparation of Standard Solutions}

Stock solutions of purine and pyrimidine bases were prepared by weighing of the required amount of particular substance and then dissolved in 1 or $2 \mathrm{ml}$ of $1 \mathrm{M} \mathrm{NaOH}$ and diluted with water to the final concentrations 10.0 or $1.0 \mathrm{mM}$. Solutions were stored in refrigerator and prepared fresh each month. Working standards were prepared daily from stock solutions and diluted with mobile phase solution.

\section{4. Sample Preparation}

Three types of samples were used for determination of purine and pyrimidine bases: saliva, urine and beer. Since we intended primarily to estimate the concentration levels of free nucleobases in samples, we did not employ any rigorous sample pretreatment or acid hydrolysis of samples as usually applied when total amounts of nucleobases in samples were determined. ${ }^{3,7,9,12-13,15,20-22}$ For the HPLC analysis beer samples (alcoholic and nonalcoholic samples of local producers) were degassed to eliminate 
dissolved $\mathrm{CO}_{2}$ and diluted with mobile phase MP2 at a ratio 1:20.

Saliva samples taken from healthy male volunteer (24 years old) according to ethical standards were first centrifuged for 30 minutes and then the supernatant phase was filtered through $0.22 \mu \mathrm{m}$ membrane filters and then diluted in a ratio $1: 5(\mathrm{v} / \mathrm{v})$ with $50 \mathrm{mM}$ acetate buffer.

Urine samples were also taken from healthy male volunteer (24 years old) in compliance with ethical standards, sonificated for 30 minutes and then diluted in a ratio of $1: 5$ with $50 \mathrm{mM}$ acetate buffer, and uric acid was determined in 100 times diluted samples.

\section{Results and Discussion}

\section{1. Optimization of Chromatographic Conditions for Separation of Purine and Pyrimidine Bases}

The choice of an appropriate $\mathrm{pH}$ of the mobile phase for separation of purine and pyrimidine bases on RP column is very important because of amphiprotic properties of these compounds and reactions with the solvent. As emphasized by Haunschmidt et al. ${ }^{18}$ electrolyte-solute interactions may significantly affect separation selectivity by electromigration techniques too, where degree of ionization of nucleobases is crucial for the separation mechanisms as well as the migration rate. In Table 1 the distribution of major species for some bases at different $\mathrm{pH}$ was calculated on the basis of data published in literature. ${ }^{28-30}$ As can be seen some of the bases do not change its predominant form markedly in the $\mathrm{pH}$ range between 4.0 and 5.5 (e.g. uracil, xanthine and tymine), but most of them change fraction of its protonated, neutral or deprotonated form substantially when $\mathrm{pH}$ was changed from 4.0 to 5.5 (or more). For example cytosine, cytidine and adenine exist at $\mathrm{pH} 4.0$ predominantly in their protonated form $\left(\mathrm{H}_{3} \mathrm{~A}^{+}\right)$, and at $\mathrm{pH} 5.5$ their neutral (zwitterionic) species prevail. Also uric acid (UA) change from its almost completely protonated form at $\mathrm{pH} 4.0$ to fully deprotonated form $\mathrm{HA}^{-}$at $\mathrm{pH}$ 5.5. Because of protolytic equilibria electrostatic interactions between analytes and solvent may affect retention of these substances and can influence the quality of the chromatographic separation.

To confirm this assumption, chromatographic separation of nine bases on RP column was performed. Chromatogram shown in Figure 1 was performed in a mixture of $50 \mathrm{mM}$ phosphate buffer of different $\mathrm{pH}(4.0-5.5)$ with $3 \%$ of methanol (MP1). Due to the low content of methanol in the mobile phase, it was assumed that addition of $\mathrm{MeOH}$ to the buffer does not change $\mathrm{pH}$ of the hydroorganic mixture substantially. ${ }^{31-32}$ From Figure 1 it can be seen that retention of uric acid, guanosine and adenine is markedly affected by $\mathrm{pH}$. At $\mathrm{pH} 5.5$ peaks are quite symmetrical and narrow but the chromatographic resolution $(R)$ was poor, and at $\mathrm{pH} 4.0$ it improves substantially and all bases were separated on the base line $(R>3.6)$. Better separation at lower $\mathrm{pH}$ confirms also the number of theoretical plates $N$ which for CS, UR and UA increased at $\mathrm{pH} 4.0$ for 3000-5000. Note that $N$ were calculated from the width at half the peak height $\left(W_{0.5}\right)$ by following equation: $N=5.54\left(\frac{t_{r}}{W_{0.5}}\right)^{2}$. By repeated measurements in MP1 we have found that the retention times for the bases were not reproducible enough between measurements and between days. Very poor reproducibility of the retention time we observed by cytosine (CV 3.4\%) and especially by adenine (CV 11\%), where peaks are occasionally splitted thus indicating that two species of the compound coexist.

The reason for the irreproducibility of retention times lies in our opinion mainly in the poor buffer capacity of phosphate buffer at $\mathrm{pH}$ below 6 . Because ofdissociation constants of phosphoric acid $\left(\mathrm{p} K_{\mathrm{a} 1} 2.148, \mathrm{p} K_{\mathrm{a} 2} 7.199\right)$, mixtures of $\mathrm{H}_{3} \mathrm{PO}_{4} / \mathrm{H}_{2} \mathrm{PO}_{4}^{-}$and $\mathrm{H}_{2} \mathrm{PO}_{4}{ }^{-} / \mathrm{HPO}_{4}{ }^{2-}$ have good buffering properties at $\mathrm{pH}$ close to their $\mathrm{p} K_{\mathrm{a}}$ values, respectively. As can be seen from Figure 2, where buffer ca-

Table 1. Calculated distribution coefficients for nucleobase species at different $\mathrm{pH}^{*}$

\begin{tabular}{|c|c|c|c|c|c|c|c|c|c|}
\hline \multirow[b]{2}{*}{ Base/Species } & \multicolumn{3}{|c|}{$\mathrm{pH}=4.0$} & \multicolumn{3}{|c|}{$\mathrm{pH}=4.3$} & \multicolumn{3}{|c|}{$\mathrm{pH}=5.5$} \\
\hline & $\mathbf{H}_{3} \mathbf{A}^{+}$ & $\mathbf{H}_{2} \mathbf{A}$ & $\mathbf{H A}^{-}$ & $\mathbf{H}_{3} \mathbf{A}^{+}$ & $\mathbf{H}_{2} \mathbf{A}$ & $\mathbf{H A}^{-}$ & $\mathbf{H}_{3} \mathbf{A}^{+}$ & $\mathbf{H}_{2} \mathbf{A}$ & $\mathbf{H A}^{-}$ \\
\hline$\overline{\text { Cytosine }(\mathrm{CS})}$ & 0.799 & 0.201 & $<0.001$ & 0.666 & 0.334 & $<0.001$ & 0.112 & 0.888 & $<0.001$ \\
\hline Uracil (UR) & & 1.000 & $<0.001$ & & 1.000 & $<0.001$ & & 1.000 & $<0.001$ \\
\hline Cytidine (CD) & 0.557 & 0.443 & $<0.001$ & 0.387 & 0.613 & $<0.001$ & 0.038 & 0.962 & $<0.001$ \\
\hline Uric Acid (UA) & & 0.962 & 0.038 & & 0.926 & 0.074 & & 0.443 & 0.557 \\
\hline Hypoxanthine (HY) & 0.006 & 0.994 & $<0.001$ & 0.003 & 0.997 & $<0.001$ & $<0.001$ & 0.999 & 0.001 \\
\hline Xanthine (XA) & & 1.000 & $<0.001$ & & 0.999 & 0.001 & & 0.990 & 0.010 \\
\hline Tymine (TM) & & 1.000 & $<0.001$ & & 1.000 & $<0.001$ & & 1.000 & $<0.001$ \\
\hline Adenine (AD) & 0.613 & 0.387 & $<0.001$ & 0.443 & 0.557 & $<0.001$ & 0.048 & 0.952 & $<0.001$ \\
\hline Guanosine (GU) & 0.008 & 0.992 & $<0.001$ & 0.004 & 0.996 & $<0.001$ & $<0.001$ & 1.000 & $<0.001$ \\
\hline Guanine (GUA) & 0.166 & 0.834 & $<0.001$ & 0.091 & 0.909 & $<0.001$ & 0.006 & 0.994 & $<0.001$ \\
\hline
\end{tabular}

*Data on thermodynamic quantities and protonation constants are taken from ref. ${ }^{28-30}$ 

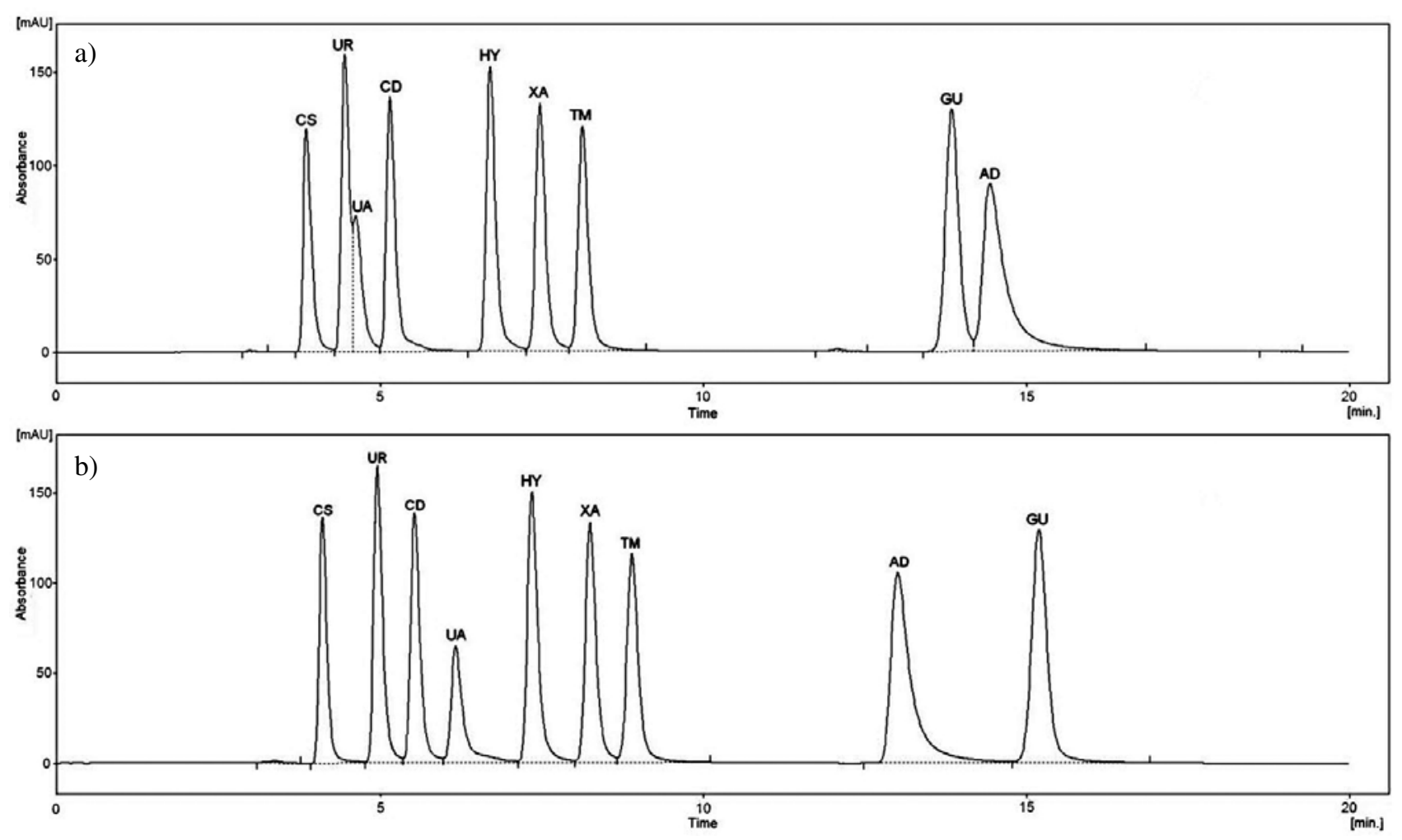

Figure 1. Chromatogram of a mixture of $50 \mu \mathrm{M}$ bases in $0.05 \mathrm{M}$ phosphate buffer with $3 \%(\mathrm{v} / \mathrm{v}) \mathrm{MeOH}$ at $\mathrm{pH}$ a) 5.5 and b) 4.0 .

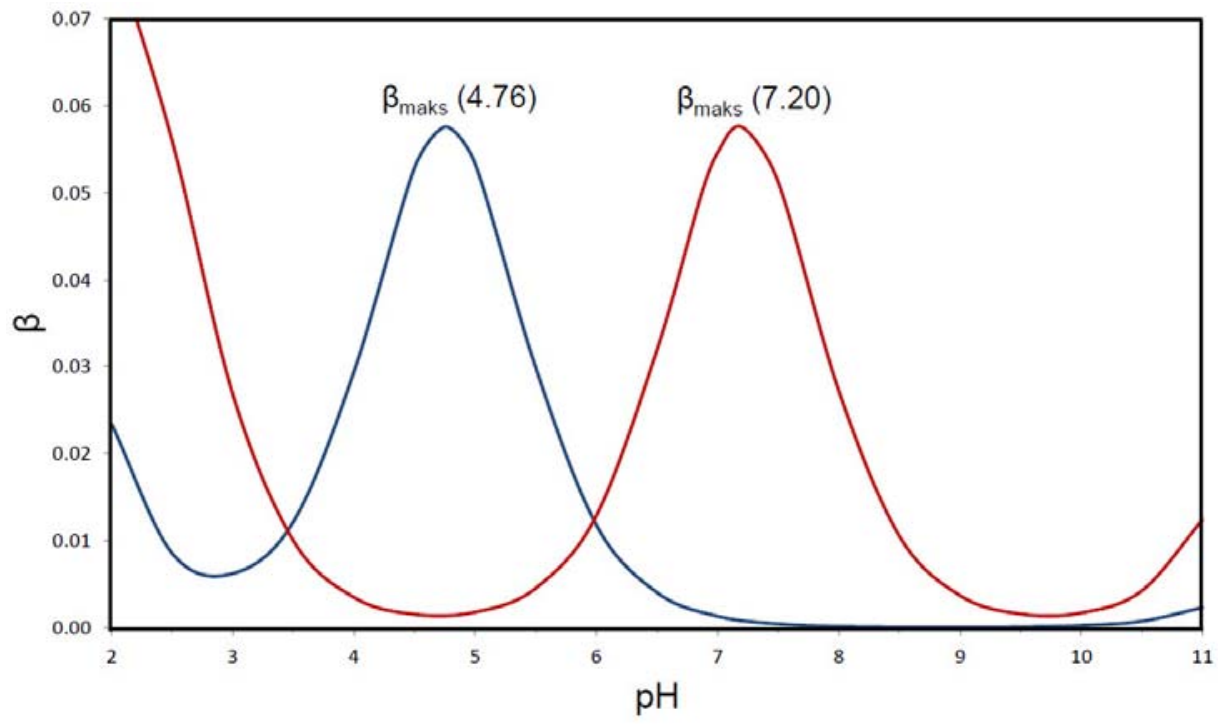

Figure 2. Calculated buffer capacity at different $\mathrm{pH}$ for a) $0.10 \mathrm{M}$ acetate and b) $0.05 \mathrm{M}$ phosphate buffer.

pacity of phosphate (curve a) and acetate (curve b) buffer was calculated, $\mathrm{H}_{2} \mathrm{PO}_{4}{ }^{-} / \mathrm{HPO}_{4}{ }^{2-}$ buffer has a maximum capacity at $\mathrm{pH} 7.20$ and cannot keep pH of the mobile phase constant enough at $\mathrm{pH}$ below 5.5 where optimal separation was found. To ensure constant $\mathrm{pH}$ and thus the degree of ionization of the nucleobases during the separation, we applied acetate buffers, which have maximal buffering strength at $\mathrm{pH} 4.76$ (Figure 2, curve a) and are able to keep stable $\mathrm{pH}$ of the mobile phase between 3.7 and 5.7. Acetate buffers are also preferred when mass spectrometric detection was combined with the LC separation. ${ }^{20,22}$ 
As can be seen from Figure 3a, with this mobile phase MP2 a complete separation of all nine bases on the base line was achieved and the retention times did not change significantly during the subsequent measurements or between days. As seen from Figure 3 concentration of buffer also influence retention of particular substances. Increased concentration of buffer (ionic strength) decreases retention of all substances and especially of those bases with higher retention times. An exception is adenine (AD), whose retention is not influenced by buffer concentration, but it is highly sensitive to $\mathrm{pH}$ of mobile phase. An increase of $\mathrm{pH}$ from 4.0 to 4.3 increases the retention time of $\mathrm{AD}$ for approximately 3 minutes where it is then coeluted with guanosine. At $0.2 \mathrm{M}$ buffer (Fig. 3c) peaks for CS and $\mathrm{AD}$ became broader and a shoulder on both peaks indicate the presence of two major species. This can be explained by the change of the activity coefficients and consequent change of the $\mathrm{pH}$ at higher ionic strength of the mobile phase. As evident from Table 1 the concentration of protonated $\mathrm{H}_{3} \mathrm{~A}^{+}$and zwitterionic $\mathrm{H}_{2} \mathrm{~A}$ species of both $\mathrm{CS}$ and $\mathrm{AD}$ highly depend on $\mathrm{pH}$ in the range between $\mathrm{pH}$ 4 and $\mathrm{pH} 4.3$. This is another evidence that the $\mathrm{pH}$ of the mobile phase should be constant during the separation of ionizable substances as were the investigated nucleobases. Despite of these observations $\mathrm{pH}$ of the mobile phase should be kept constant at $\mathrm{pH} 4.0 \pm 0.1$ and the total concentration of the buffer should be at least $50 \mathrm{mM}$ and below $0.2 \mathrm{M}$.
Optimal concentration of $\mathrm{MeOH}$ content in the mobile phase was also searched for. At $10 \%(\mathrm{v} / \mathrm{v})$ of Me$\mathrm{OH}(50 \mathrm{mM}$ acetate buffer of $\mathrm{pH} 4.0)$, retention of all bases decreased $\left(t_{\mathrm{r}}(\mathrm{CS})=3.8 \mathrm{~min}, t_{\mathrm{r}}(\mathrm{GU})=8 \mathrm{~min}\right)$, and separation of bases was not complete. When the fraction of $\mathrm{MeOH}$ was decreased to $2 \%$, the separation of nucleobases was perfect, but the retention was significantly longer and the elution of guanosine as the most retained compound, appears no sooner than at $15.5 \mathrm{~min}$. As a compromise between analysis time and resolution, the content of $\mathrm{MeOH}$ should be $3.0 \pm 0.5 \%$ (v/v). It should be noted that for LC/MS/MS analysis a more volatile ammonium acetate was used instead of sodium acetate for preparation of the acetate buffer (MP3).

As mentioned in the Experimental section, UV detection at $254 \mathrm{~nm}$ was applied for detection and quantification of nucleobases. This wavelength is a compromise while all observed nucleobases dissolved in MP2 of $\mathrm{pH}$ 4.0, shows at least two absorption maxima in the range between 190 and $330 \mathrm{~nm}$, and with the exception of guanosine, absorbance peaks at longer wavelengths $(250-290 \mathrm{~nm})$ are higher than by the first peaks appearing at shorter $\lambda(210-230 \mathrm{~nm})$. The measurements at $254 \mathrm{~nm}$ were therefore not optimal and can be further optimized when only particular substance or a group of bases with similar absorptivity were measured. Also the use of diode array detector is recommended to optimize sensitivity of particular bases in the mixture.
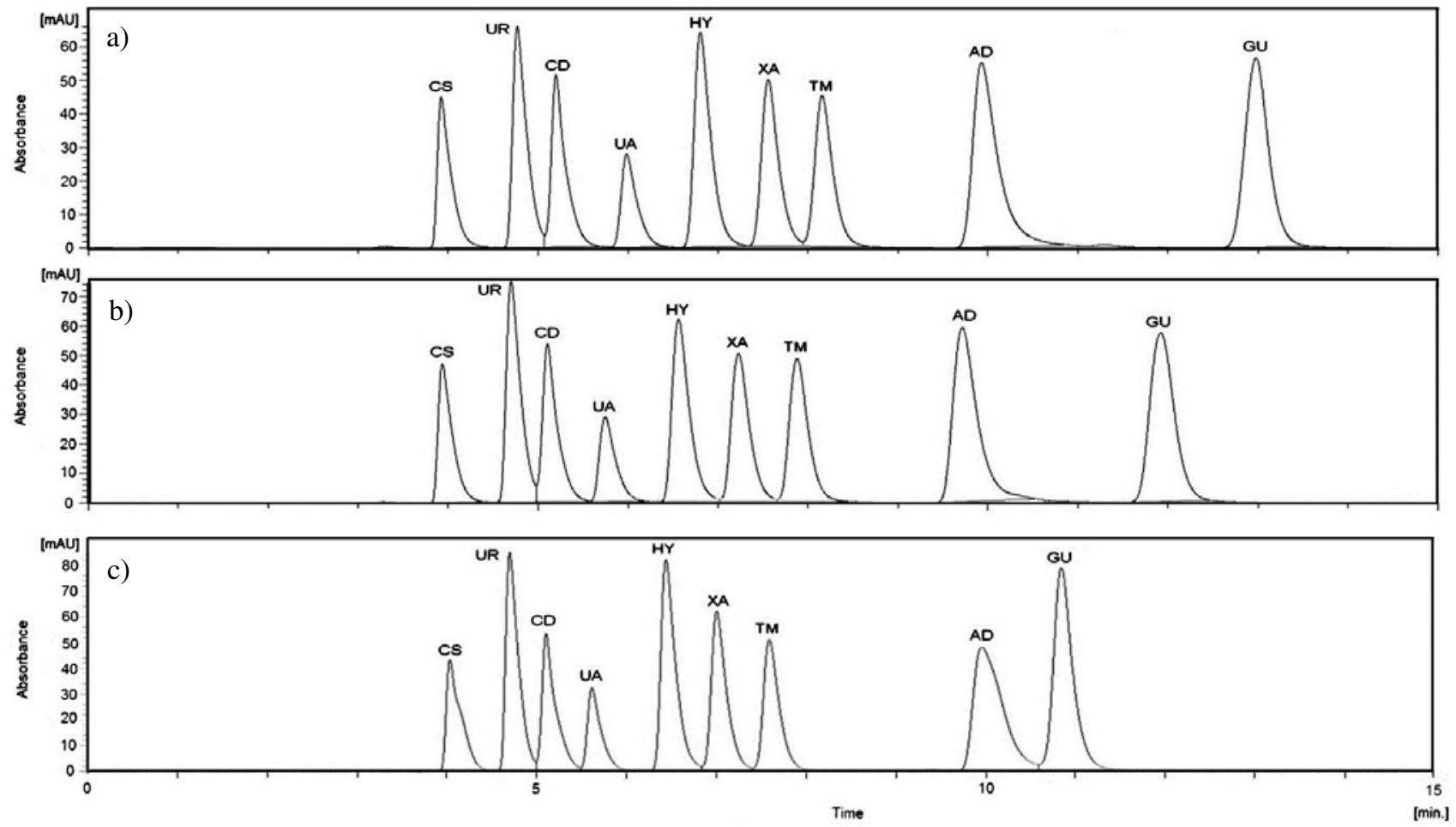

Figure 3. Chromatograms of nine $50 \mu \mathrm{M}$ nucleobases in acetate buffer of $\mathrm{pH} 4.0$ and 3\% $\mathrm{MeOH}$ of different total concentrations: a) $0.05 \mathrm{M}$, b) 0.1 $\mathrm{M}$, and c) $0.2 \mathrm{M}$. 


\section{2. Stability of Studied Nucleobases}

For practical work information about the stability of the working standards prepared in different mobile is needed. Since nucleobases are prone do decomposition, stability of working solutions at $50 \mu \mathrm{M}$ level and at room temperature $\left(22 \pm 2{ }^{\circ} \mathrm{C}\right)$ was performed in both phosphate MP1 and acetate MP2 mobile phases. It was found that in phosphate buffer of $\mathrm{pH} 5.5$ uric acid, xanthine and hypoxanthine decomposes more than $95 \%$ in one day, and other substances (CS, UR, TM, AD, GU) degrade more than $50 \%$ in four days. The most stable was cytidine and its concentration decreases in four days for 5\% only. The reason for degradation may lie in the nucleophilic properties of phosphate, contamination with traces of metallic or bacterial impurities, photochemical reactions, etc. Surprisingly, the stability of working solutions of particular bases and their mixture in the $0.1 \mathrm{M}$ acetate buffer of $\mathrm{pH} 4$ was significantly better and with the exception of guanosine, after 50 days concentration of bases decreases less than $5 \%$ at room temperature. Guanosine decomposes more rapidly and almost linearly with time and on the chromatograms two new peaks appeared at 6.8 and 7.2 min, and the last one is higher and overlapped with hypoxanthine peak. By LC/MS/MS system in MRM mode (negative ionization) it was found that the peak at $7.2 \mathrm{~min}$ belongs to guanine produced from guanosine by splitting off its sugar moiety. It can be concluded that working solutions of nucleobases are stable for at least three weeks at room temperature when prepared in acetate buffer of $\mathrm{pH}$ 4 , and when GU is also a target analyte, working solution of GU or mixture of bases should be prepared fresh daily.

\section{3. Validation of Analytical Method}

The linearity, regression and linear ranges of nine nucleobases were determined using the optimized HPLC method (MP2). The correlation coefficient $\left(\mathrm{R}^{2} \geq 0.9994\right)$ showed good correlation between concentrations of inve- stigated compounds and peak areas within the test range $(1-50 \mu \mathrm{M})$. The limits of detection (LOD) and quantification (LOQ) were lower than $0.5 \mu \mathrm{M}$ and $1 \mu \mathrm{M}$, respectively (Table 2 ).

To determine precision of the results obtained by the method, mixed working standard solutions of nine nucleobases on different level $(1,5,10$ and $50 \mu \mathrm{M})$ were analyzed in triplicates. As seen (Table 2) the overall performance of the elaborated procedure was quite good and was further tested by analysis of some real samples.

\section{4. Determination of Purine and Pyrimidine Bases in Real Samples}

Purine and pyrimidine bases were determined in alcoholic and nonalcoholic beer samples, saliva and urine samples of healthy volunteer. Before analysis of the samples the calibration curves in the range $1-50 \mu \mathrm{M}$ were prepared for nine nucleobases. Content of bases in each sample was determined via calibration curve and with a standard addition method. We should note that this method was developed primarily as a screening one to obtain information on the concentration levels of the investigated analytes and matrix constituents of investigated samples. In practice this information is important for diagnostic purposes, e.g. food analysis, clinical investigations etc. As shown in Figure 4 analyzed beer sample contained beside of nine identified nucleobases, also numerous other unknown compounds. Only cytidine, xanthine, adenine and guanosine are well resolved and can be quantified reliably. Determination of other assigned nucleobases should be performed after a proper clean-up pretreatment of samples and by a multiple standard addition procedure because of complexity of the matrix (Figure 4). For example for determination of cytosine we used pretreatment of samples on strong anion exchange column for elimination of interfering matrix compounds in beer samples. It should be noted that analysis of beer samples are very time consuming due to a slow elution of other matrix con-

Table 2. Linear regression data (correlation coefficient $\mathrm{R}^{2}$, limit of detection LOD $(\mu \mathrm{M})$, limit of quantitation LOQ $(\mu \mathrm{M})$, and coefficient of variation $\mathrm{CV}(\%)$ ) of nine investigated nucleobases in the range between 1 and $50 \mu \mathrm{M}$; sample volume was $20 \mu \mathrm{L}$.

\begin{tabular}{|c|c|c|c|c|c|c|}
\hline Analyte & $\begin{array}{l}\text { Regression equation } \\
Y=\mathbf{a} x+\mathbf{b}^{\mathrm{a}}\end{array}$ & $\mathbf{R}^{2}$ & LOD $(\mu \mathrm{M})$ & $\operatorname{LOQ}(\mu \mathrm{M})$ & $\mathrm{CV}(\%) 1 \mu \mathrm{M}$ & $\mathrm{CV}(\%) 10 \mu \mathrm{M}$ \\
\hline$\overline{\text { Cytosine (CS) }}$ & $Y=0.176 x+0.004$ & 1.0000 & 0.2 & 0.6 & 0.6 & 0.9 \\
\hline Uracil (UR) & $Y=0.278 x-0.072$ & 0.9994 & 0.2 & 0.5 & 1.9 & 1.0 \\
\hline Cytidine (CD) & $Y=0.214 x-0.086$ & 0.9994 & 0.3 & 0.6 & 0.7 & 0.3 \\
\hline Uric Acid (UA) & $Y=0.121 x-0.039$ & 0.9998 & 0.4 & 1.0 & 0.6 & 2.0 \\
\hline Hypoxanthine (HY) & $Y=0.293 x-0.016$ & 0.9999 & 0.2 & 0.5 & 0.9 & 0.2 \\
\hline Xanthine (XA) & $Y=0.238 x-0.032$ & 0.9999 & 0.2 & 0.6 & 1.3 & 0.5 \\
\hline Tymine (TM) & $Y=0.234 x-0.004$ & 1.0000 & 0.2 & 0.6 & 2.5 & 0.6 \\
\hline Adenine (AD) & $Y=0.391 x-0.090$ & 0.9999 & 0.3 & 0.6 & 2.4 & 0.2 \\
\hline Guanosine (GU) & $Y=0.366 x-0.121$ & 0.9999 & 0.3 & 0.6 & 1.1 & 0.5 \\
\hline
\end{tabular}

${ }^{\mathrm{a}} Y$ denote peak area (mAU.min), and $x$ analyte concentration $(\mu \mathrm{M})$ 


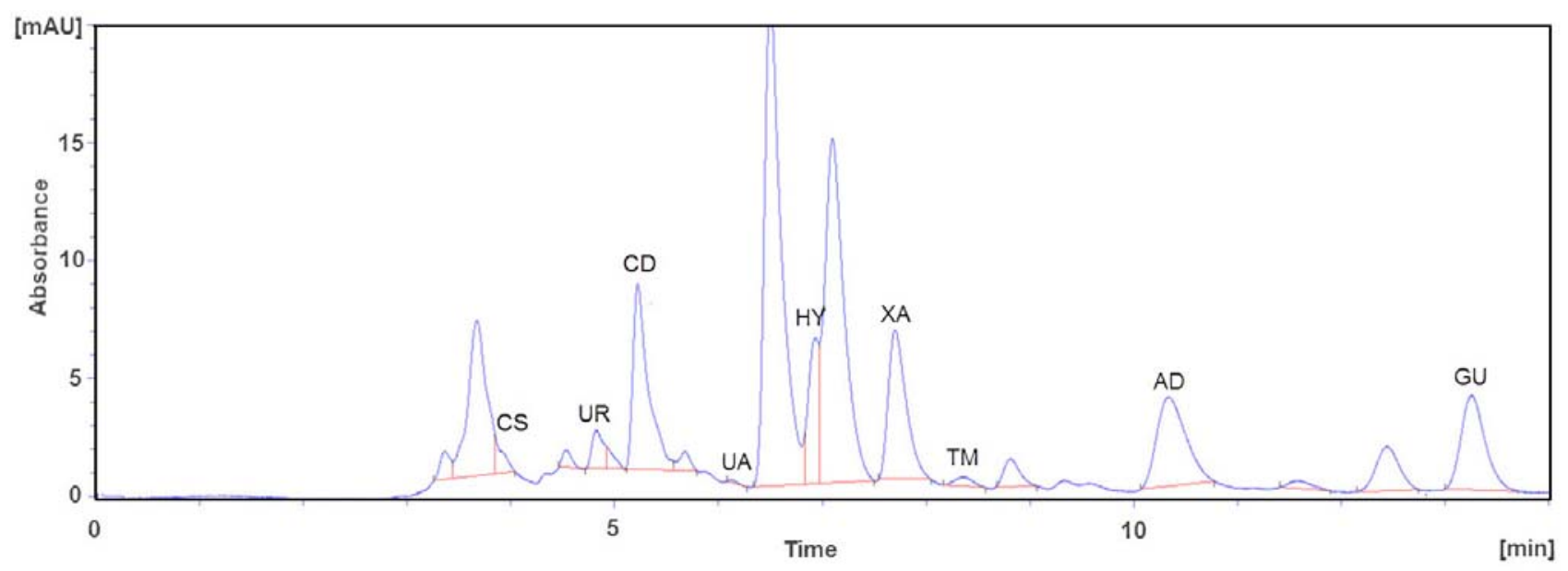

Figure 4. Chromatogram of 1:20 diluted alcoholic beer sample. Mobile phase was $50 \mathrm{mM}$ acetate buffer of pH 4.0 and $3 \%(\mathrm{v} / \mathrm{v}) \mathrm{MeOH}$.

stituents, and $40 \mathrm{~min}$ should be required to complete an isocratic analysis. In both alcoholic and non-alcoholic beers major constituents were found to be cytidine, xanthine, adenine and guanosine. Contents of these compounds in alcoholic beers (two types of lager beer) were 182-231 $\mu \mathrm{M}, 79-131 \mu \mathrm{M}, 8,5-34 \mu \mathrm{M}$, and 187-288 $\mu \mathrm{M}$, respectively, whereas in non-alcoholic beer they were 128-135 $\mu \mathrm{M}, 28-31 \mu \mathrm{M}, 179-214 \mu \mathrm{M}$, and 203-232 $\mu \mathrm{M}$, respectively. Total concentration of all investigated nucleobases found in alcoholic and non-alcoholic beer were similar, i.e. 533-664 $\mu \mathrm{M}$ and 638-678 $\mu \mathrm{M}$, respectively. Similar relative concentration ranges were also found by Kaneko et al. ${ }^{12}$

Saliva has become an important resource for evaluating physiological conditions in humans. ${ }^{33}$ Since salivary uric acid correlate with serum uric acid concentration it became a noninvasive biomarker of metabolic syndro- me. ${ }^{34}$ In saliva just uric acid was found undoubtedly and its nice peak appeared at $6.2 \mathrm{~min}$ (Figure 5). The concentration of UA in this sample equals $16 \mu \mathrm{g} / \mathrm{mL}(94 \mu \mathrm{M})$, and the reproducibility of the measurements was quite good (CV 1.1\%). It was found that the content of UA in saliva of the same person varied between different days for about $50 \%$, and to acquire reliable information on its average concentration, sampling over a longer period should be performed. Concentrations of other nucleobases investigated in this work cannot be estimated in saliva and are below LOD $(<0.1 \mu \mathrm{M})$ of this procedure.

From the chromatogram of urine shown in Figure 6, it can be seen that peaks for cytidine and guanosine are absent, and that all other bases are identified and can be quantified. Due to the presence of other unknown matrix components in the sample peaks for cytosine, uracil, hypoxanthine and tymine are not completely resolved and

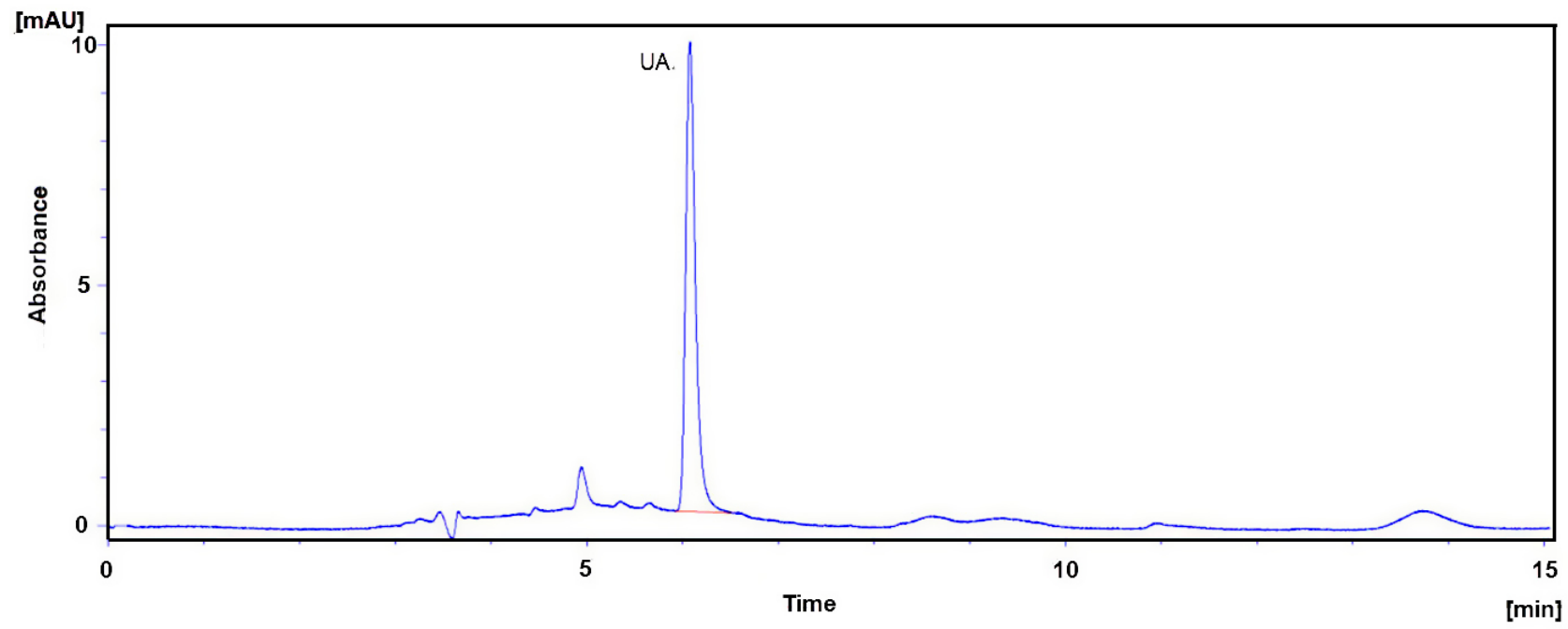

Figure 5. Chromatogram of 1:5 diluted saliva sample. Mobile phase $50 \mathrm{mM}$ acetate buffer of $\mathrm{pH} 4.0$ and 3\% (v/v) $\mathrm{MeOH}$. 


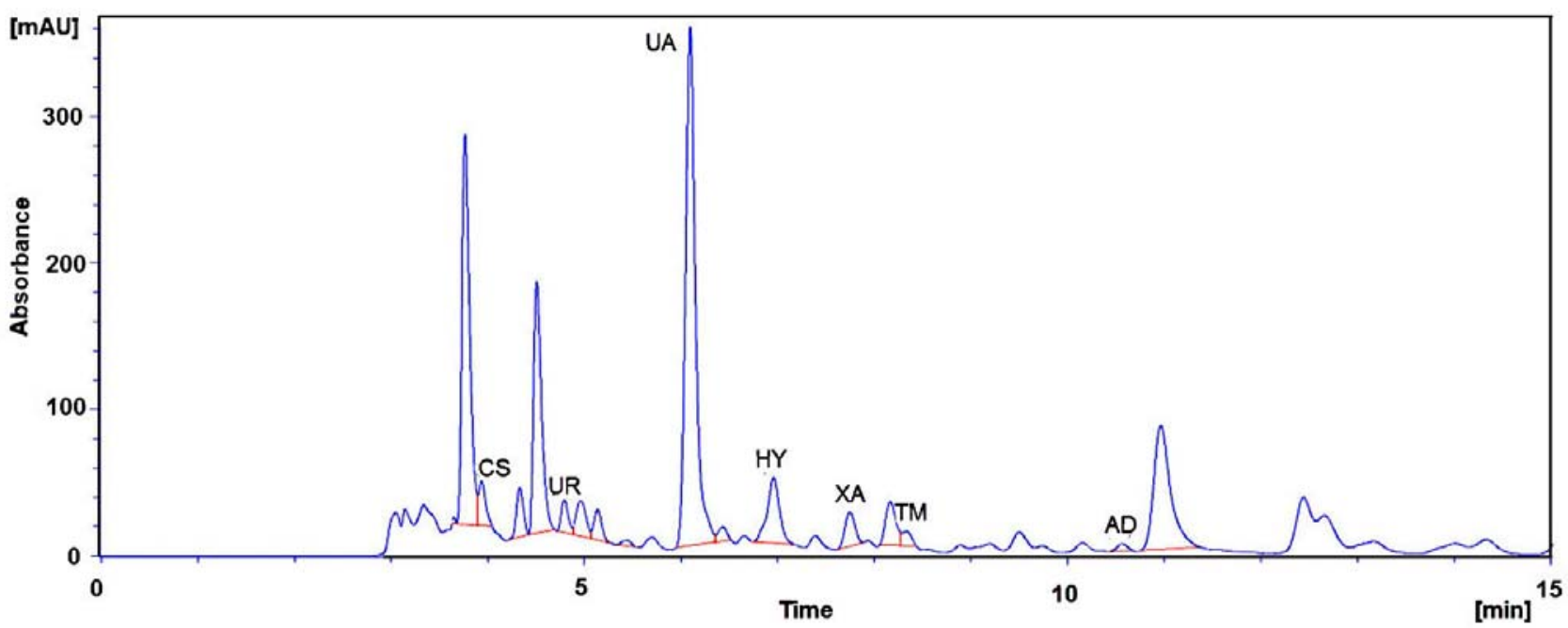

Figure 6. Chromatogram of 1:5 diluted urine sample. Mobile phase $50 \mathrm{mM}$ acetate buffer of $\mathrm{pH}$ 4.0, 3\% (v/v) $\mathrm{MeOH}$.

their concentration levels was estimated by standard addition approach. When these analytes present a target nucleobases only an appropriate clean-up procedure should be applied prior the HPLC analysis.

Peaks for uric acid, xanthine and adenine are separated and can be reliably determined via calibration curve or by a standard addition procedure. High unknown peak coeluted with cytosine at $3.8 \mathrm{~min}$ was analyzed with LC/MS/MS detection in TIC mode and it was found that two fragments with $\mathrm{m} / \mathrm{z} 144$ and 227 (positive polarity) belong to this compound. The concentrations and the repeatability of the results for bases in urine sample are collected in Table 3. Samples were taken and analyzed in a period of two months and the average concentrations and reproducibility between run and within three subsequent measurements of the same sample are given. As mentioned in Experimental, due to high concentration of UA in urine samples determination of UA was performed in 100 times diluted samples and reproducibility was quite satisfactory (CV 1\%). Uncertainty of the analytical results of other bases was typically within run between 6 and $16 \%$ (CV). But the variation of concentrations of nucleobases in urine over a longer period (two months) was found to be higher as can be seen from the results in Table 3, where deviation from the average values was between 30 and $80 \%(\mathrm{CV})$. For routine analysis of nucleobases in beer and urine samples, an appropriate sample clean-up procedure for elimination of major interfering matrix constituents should be applied to improve accuracy and reproducibility of the analytical results.

\section{Conclusions}

Reversed-phase HPLC screening method with UV detection at $254 \mathrm{~nm}$ was optimized and applied for the separation and determination of nine nucleobases of biological importance. Purine and pyrimidine bases are ionizable compounds and concentration of their species highly depends on the $\mathrm{pH}$ of the mobile phase. We found that phosphate buffers frequently used in the literature for the separation of purine and pyrimidine bases on RP-HPLC systems, do not ensure repeatable separation and we applied acetate buffer instead with much better buffering capacity at desirable $\mathrm{pH}$ of $4.0 \pm 0.1$. In the mobile phase consisting of $50 \mathrm{mM}$ acetate buffer of $\mathrm{pH} 4.0$ and $3 \%$ of

Table 3. Results of concentrations of nucleobases in urine samples.

\begin{tabular}{lccccc}
\hline Compound & $\boldsymbol{c}_{\text {average }}(\boldsymbol{\mu M})$ & $\boldsymbol{c}_{\boldsymbol{m i n}}(\boldsymbol{\mu M})^{\mathbf{a}}$ & $\boldsymbol{c}_{\boldsymbol{m a x}}(\boldsymbol{\mu M})^{\mathbf{a}}$ & $\mathbf{C V \%}^{\mathbf{a}}$ & $\mathbf{C V}^{\mathbf{b}}$ \\
\hline CS & 73 & & & & 7.6 \\
UR & 40 & 22 & 59 & 47 & 10 \\
UA & 3041 & 1544 & 3685 & 66 & 1,0 \\
HY & 67 & 30 & 66 & 39 & 16 \\
XA & 42 & 22 & 49 & 33 & 6.4 \\
TM & 29 & 1 & 11 & 73 & 12 \\
AD & 6 & & & & 14 \\
\hline
\end{tabular}

${ }^{\mathrm{a}}$ Inter-day variation of the concentration over two months $(\mathrm{n}=3),{ }^{\mathrm{b}}$ Intra-day precision of single analysis in triplicate. 
methanol (v/v), all nine bases were separated on the base line in less than $15 \mathrm{~min}$. Response of these analytes are linear in a wide range of concentrations between the detection limits $(0.5 \mu \mathrm{M})$ and up to more than $1 \mathrm{mM}$ levels. The optimized method was applied for the determination of purine and pyrimidine bases in some beer, saliva and urine samples. The variation of nucleobases concentration in these samples over a longer period was found to be up to 10 times larger than the reproducibility of the results of a single series. To obtain reliable and accurate results for the nucleobases by analysis of clinical, food and beverage samples, more attention should be made to acquire really representative samples for the analysis.

\section{Acknowledgement}

This work was supported by the Slovenian Research Agency through the Program P1-0153 and the Young Researchers Program (JM).

\section{References}

1. D. Voet, J. G. Voet, C. W. Pratt, Fundamentals of Biochemistry 2nd Edition, John Wiley\& Sons, Hoboken, NJ, USA, 2006.

2. K. Safranow, Z. Machoy, K. Ciechanowski, Anal. Biochem. 2000, 286, 224-230.

http://dx.doi.org/10.1006/abio.2000.4790

3. S. Giannattasio, S. Gagliardi, M. Samaja, E. Marra, Brain Research Protocols 2003, 10, 168-174. http://dx.doi.org/10.1016/S1385-299X(02)00215-5

4. C. Vidotto, D. Fousert, M. Akkermann, A. Griesmacher, M. M. Muller, Clin. Chim. Acta 2003, 335, 27-32. http://dx.doi.org/10.1016/S0009-8981(03)00291-2

5. K. Safranow, Z. Machoy, J. Chromatogr. B 2005, 819, 229235. http://dx.doi.org/10.1016/j.jchromb.2004.11.013

6. P. G. del Moral, M. J. Arin, J. A. Resines, M. T. Díez, J. Chromatogr. B 2005, 826, 257-260.

http://dx.doi.org/10.1016/j.jchromb.2005.07.044

7. H. Fan, F. Q. Yang, S. P. Li, J. Pharm And Biomed. Analysis 2007, 45, 141-144.

http://dx.doi.org/10.1016/j.jpba.2007.02.032

8. S. E. Khayyal, M. M. Ayad, Anal. Lett. Pt. B 1983, 16, 1525-1535. http://dx.doi.org/10.1080/00032718308069544

9. S. L. B. López, J. Moal, F. S. J. Serrano, J. Chromatogr. A 2000, 891, 99-107. http://dx.doi.org/10.1016/S0021-9673(00)00637-3

10. M. Pineiro-Sotelo, A. R. B. de Quirós, J. López-Hernández, J. Simal-Lozano, Food Chem. 2002, 79, 113-117. http://dx.doi.org/10.1016/S0308-8146(02)00173-5

11. L. Monser, Chromatographia 2004, 59, 455-459. http://dx.doi.org/10.1365/s10337-004-0223-y

12. K. Kaneko, T. Yamanobe, S. Fujimori, Biomed. Chromatogr. 2009, 23, 858-864. http://dx.doi.org/10.1002/bmc.1197
13. M. Clariana, M. Gratacós-Cubarsí, M. Hortós, J. A. GarciaRegueiro, M. Castellari, J. Chromatogr. A 2010, 1217, 4294-4299. http://dx.doi.org/10.1016/j.chroma.2010.04.033

14. N. Yamaoka, Y. Kudo, K. Inazawa, S. Inagawa, M. Yasuda, K. I. Mawatari, K. Nakagomi, K. Kaneko, J. Chromatogr. B 2010, 878, 2054-2060. http://dx.doi.org/10.1016/j.jchromb.2010.05.044

15. D. Dipierro, B. Tavazzi, C. F. Perno, M. Bartolini, E. Balestra, R. Calio, B. Giardina, G. Lazzarino, Anal. Biochem. 1995, 231, 407-412. http://dx.doi.org/10.1006/abio.1995.0071

16. C. W. Klampfl, M. Himmelsbach, W. Buchberger, H. Klein, Anal. Chim. Acta 2002, 454, 185-191. http://dx.doi.org/10.1016/S0003-2670(01)01570-7

17. P. Wang, J. C. Ren, J. Pharm And Biomed. Analysis 2004, 34, 277-283. http://dx.doi.org/10.1016/S0731-7085(03)00502-8

18. M. Haunschmidt, W. Buchberger, C. W. Klampfl, J. Chromatogr. A 2008, 1213, 88-92. http://dx.doi.org/10.1016/j.chroma.2008.09.063

19. G. Chen, Q. C. Chu, L. Y. Zhang, J. N. Ye, Anal. Chim. Acta 2002, 457, 225-233. http://dx.doi.org/10.1016/S0003-2670(02)00027-2

20. S. Al-Shehri, M. Henman, B. G. Charles, D. Cowley, P. N. Shaw, H. Liley, A. Tomarchio, C. Punyadeera, J. A. Duley, J. Chromatogr. B 2013, 931, 140-147. http://dx.doi.org/10.1016/j.jchromb.2013.05.001

21. C. D. Laourdakis, E. F. Merino, A. P. Neilson, M. B. Cassera, J. Chromatogr. B 2014, 967, 127-133. http://dx.doi.org/10.1016/j.jchromb.2014.07.012

22. C. Stentoft, M. Vestergaard, P. Løvendahl, N. B. Kristensen, J. M. Moorby, S. K. Jensen, J. Chromatogr. A 2014, 1356, 197-210. http://dx.doi.org/10.1016/j.chroma.2014.06.065

23. E. Palecek, Anal. Lett. Pt. B 1980, 13, 331-345. http://dx.doi.org/10.1080/00032718008059787

24. P. A. M. Farias, A. D. R. Wagener, A. A. Castro, Anal. Lett. 2001, 34, 2125-2140. http://dx.doi.org/10.1081/AL-100106844

25. S. Hason,, F. Jelen, L. Fojt, V. Vetterl, J. Electroanal. Chem 2005, 577, 263-272. http://dx.doi.org/10.1016/j.jelechem.2004.11.037

26. Q. Xu, X. X. Liu, H. B. Li, L. N. Yin, X. Y. He, Biosens. Bioelectron. 2013, 42, 355-361. http://dx.doi.org/10.1016/j.bios.2012.11.004

27. C. Y. Deng, Y. L. Xia, C. H. Xiao, Z. Nie, M. H. Yang, S. H. Si, Biosens. Bioelectron. 2012, 31, 469-474. http://dx.doi.org/10.1016/j.bios.2011.11.018

28. R. M. Izatt, Christen.Jj, J. H. Rytting, Chem. Rev. 1971, 71, 439-481. http://dx.doi.org/10.1021/cr60273a002

29. Christen.Jj, J. H. Rytting, R. M. Izatt, Biochemistry 1970, 9 , 4907-4913.

30. F. H. McCrudden, Uric Acid, Bibliolife, Charleston, SC, USA, 2008.

31. J. Barbosa, D. Barron, S. Buti, Anal. Chim. Acta 1999, 389, 31-42. http://dx.doi.org/10.1016/S0003-2670(99)00133-6

32. R. Bergés, V. Sanz-Nebot, J. Barbosa, J. Chromatogr. A 2000, 869, 27-39. 
http://dx.doi.org/10.1016/S0021-9673(99)00915-2

33. D. P. Lima, D. G. Diniz, S. A. S. Moimaz, D. H. Sumida, A. C. Okamoto, Int. J. Infec. Dis 2010, 14, E184-E188.

http://dx.doi.org/10.1016/j.ijid.2009.04.022
34. M. Soukup, I. Biesiada, A. Henderson, B. Idowu, D. Rodeback, L. Ridpath, E. G. Bridges, A. M. Nazar, K. G. Bridges, Diabet. Metab. Syndr. 2012, 4.

\section{Povzetek}

Kromatografska ločba purinskih in pirimidinskih nukleobaz je zaradi amfiprotičnih lastnosti teh spojin močno odvisna od interakcij s topilom. Izračun porazdelitvenih koeficientov nekaterih nukleobaz je pokazal korelacijo med zadrževalnim časom na reverzno-fazni koloni in $\mathrm{pH}$ mobilne faze, kar si razlagamo z vplivom elektrostatskih interakcij posameznih baz s stacionarno fazo. Poleg $\mathrm{pH}$ mobilne faze je za ponovljivost retencijskih časov pomembna tudi pufrska kapaciteta, ki mora biti maksimalna blizu pH štiri, pri katerem se spojine dobro ločijo. Z optimizacijo HPLC metode smo uspeli v mobilni fazi, ki je vsebovala $50 \mathrm{mM}$ acetatni pufer s pH 4,0 $\pm 0,1$ in $3 \%$ metanol, v 15 min sočasno določiti pet purinskih (sečna kislina, ksantin, hipoksantin, adenin, gvanozin) in štiri pirimidinske baze (citozin, uracil, citidin, timin). Analiza nekaterih bioloških vzorcev in napitkov je pokazala, da je metoda primerna za hitre presejalne teste in klinično diagnostiko. 